\title{
A CASE STUDY OF THE BEHAVIOR OF AEROSOL OPTICAL PROPERTIES UNDER THE INCIDENCE OF A SAHARAN DUST INTRUSION EVENT
}

\author{
CAZACU, M. M. ${ }^{1,2^{*}}$ - TUDOSE, O. G. ${ }^{1,3}-$ TIMOFTE, A. ${ }^{1,4}-$ RUSU, O. ${ }^{1}-$ APOSTOL, L. ${ }^{5}-$ \\ LEONTIE, L. ${ }^{1}-$ GURLUI, S. ${ }^{1}$ \\ ${ }^{1}$ Alexandru Ioan Cuza University of Iasi, Faculty of Physics, Atmosphere Optics, Spectroscopy \\ and Lasers Laboratory (LOA-SL Iasi) \\ Bulevardul Carol I, nr. 11, 700506 Iasi, Romania, \\ ${ }^{2}$ Physics Department, Gheorghe Asachi Technical University of Iasi, \\ 59A Mangeron Blvd., 700050 Iasi, Romania \\ ${ }^{3} S C$ INOESY SRL, \\ 21 Bradului Street, RO-700660, Iasi, Romania \\ ${ }^{4}$ National Meteorological Administration, Regional Forecast Center Bacau, \\ 3 Timpului Str., Bacau, Romania \\ ${ }^{5}$ Alexandru Ioan Cuza University of Iasi, Faculty of Geography and Geology, \\ Bulevardul Carol I, nr. 11, 700506 Iasi, Romania \\ *Corresponding author \\ e-mail: cazacumarius@gmail.com; \\ phone: +40232201197; fax: +40232201150 \\ (Received 28 $8^{\text {th }}$ Jun 2015; accepted $23^{\text {rd }}$ Apr 2016)
}

\begin{abstract}
In this paper a local-scale study of Saharan dust loading over Iasi city, Romania, during July 2012 is reported. The intrusion of Saharan dust above the monitoring site [Iasi_LOASL, Romania $(47.19 \mathrm{~N}, 27.55 \mathrm{E})]$ and the variations of ozone and $\mathrm{NO}_{2}$ concentrations are estimated by using advanced remote sensing techniques (i.e. Aerosol Robotic NETwork - AERONET, Cloud-Aerosol Lidar and Infrared Pathfinder Satellite Observations - CALIPSO) and forecast models (i.e. DREAM and MAP 3D). The time interval was appropriately selected, to remove the influence of precipitation and clouds on photochemical processes. During intrusion events, the Saharan dust represents the main source for changes in optical and chemical parameters of the atmosphere.
\end{abstract}

Keywords: remote sensing, AERONET, Saharan dust, aerosols, ozone

\section{Introduction}

Taking into account the major role of aerosols in absorption and scattering of solar radiation, which alters the optical properties of Earth's atmosphere, remote sensing techniques and modeling approach have been recently developed, providing complementary information about temporal and spatial variation of aerosol optical parameters (e.g. Single Scattering Albedo, Ångstrom exponent, Lidar ratio etc.). Recent researches confirmed that in Romania, especially in urban areas, the main sources of air pollution amend the complex mechanisms of photochemical oxidants; they produce an adverse effect on the optical properties of Earth's atmosphere and global climate change (Cazacu et al., 2015, 2011; Papayannis et al., 2014). Of all the classes of photochemical oxidants in the atmosphere, ozone and nitrogen dioxide are among the most extensively 
studied; recent studies focused on the possible influence of Saharan dust on them (Ohde and Siegel, 2012).

Actual monitoring and modeling techniques for the Earth's atmosphere (Light Detection And Ranging - LIDAR, sun photometer, UV cameras, MAP3D etc.) provide useful information on changes in the weather conditions and the climate (Belegante et al., 2011; Cazacu et al., 2011; Nicolae et al., 2010; Timofte et al., 2011).

The Saharan dust significantly influences the radiative transfer through absorption, scattering and reflection phenomena, strongly affecting the energy fluxes and spectral distribution of solar radiation (Earth's radiation budget), as well as photosynthesis processes (Haywood et al., 2008; Papayannis et al., 2014). In addition to the influence of Saharan dust, radiative transfer is also affected by anthropogenic sources of nitrogen oxides ( $\mathrm{NO}$ and $\mathrm{NO}_{2}$ ) and volatile organic compounds (VOCs) under the influence of solar ultraviolet (UV) radiation, favouring photochemical reactions (Ohde and Siegel, 2012; Shon et al., 2008).

This paper presents a study of Saharan dust loading over long distances, as well as monitoring of possible influences on the atmosphere over Romania. The analysis of experimental data and theoretical models specific to Romania have shown fairly low concentrations of Saharan dust, but large enough to influence the optical parameters, so that the transfer of solar radiation is affected even during sunny days.

Some research and development projects, such as ROmanian LIdar NETwork (ROLINET) and Romanian Atmospheric research 3D Observatory (RADO) investigate the air quality in the North-East region of Romania, in the proximity of the Iasi city; several research papers reported on this topic. Starting from the end of spring to early fall, over Romania, multiple Saharan dust events occur (Cazacu et al., 2015, 2012, 2011; Gothard et al., 2014; Labzovskii et al., 2014; Papayannis et al., 2014; Unga et al., 2013). In this paper, we report the influence of Saharan dust during July 2012 on the local air quality. Besides, we compare the air quality forecast given by MAP3D with the experimental data acquired through remote sensing techniques available on the site, the Atmospheric Research 3D Observatory RADO Station of the Alexandru Ioan Cuza University of Iasi (sun photometry). Other experimental and theoretical approaches in the quantification of air quality were also used, i.e. Cloud-Aerosol Lidar and Infrared Pathfinder Satellite Observations (CALIPSO), Dust REgional Atmospheric Model (DREAM) and Hybrid Single Particle Lagrangian Integrated Trajectory Model (HYSPLIT). Evidence of Saharan dust intrusion was provided by sun photometry and by calculus methods of aerosols dispersion (based on databases of various meteorological survey stations).

\section{Methodology}

Mesoscale Air Pollution 3D Modeling (MAP3D) developed at the Laboratory of Environmental Fluid Mechanics and Hydrology of École Polytechnique Fédérale de Lausanne, Switzerland, is capable of providing daily forecasts for air pollutants $\left(\mathrm{O}_{3}\right.$, $\mathrm{NO}, \mathrm{NO}_{2}, \mathrm{PM}_{10}$ particles) (Couach et al., 2004). The MAP3D is based on the chemical model MM5/CHIMERE, which has been successfully applied for the entire Romanian territory [with a resolution of $15 \times 15 \mathrm{~km}^{2}$ (Cazacu et al., 2011)].

Complementary researches were based on the following techniques:

- Aerosol Robotic NETwork (AERONET), a NASA network for monitoring and characterizing atmospheric aerosols using a Cimel Automatic Sun Tracking Photometer 
CE 318 ground-based, solar- powered, weather-hardy, robotically-pointed sun and sky spectral photometer (Holben et al., 1998). Starting from 7 May 2012, the monitoring station Iasi_LOASL located in Iasi, Romania $(47.19 \mathrm{~N}, 27.55 \mathrm{E})$ became active in this network, giving researchers immediate access to the quantitative values for various types of aerosols (Unga et al., 2013). In order to provide optical aerosol properties the Ångstrom exponent, Single Scattering Albedo (SSA), Lidar report calculated by AERONET $\left(S_{A E R O N E T}\right)$ and size distribution were considered from level 1.5 with zenith angle larger than $50^{\circ}$, retrieval error less than 5\% and AOT (aerosol optical thickness) at $440 \mathrm{~nm}$ greater than 0.2 . The Lidar ratio is defined as ratio between extinction coefficient and backscatter coefficient and can be calculated using the SSA parameter (at $532 \mathrm{~nm}$ ) and phase function at 180 degree (Cattrall et al., 2005).

- Dust REgional Atmospheric Model (DREAM), an operational website developed by Earth Sciences Division of the Barcelona Supercomputing Center, used to confirm the presence of Saharan dust over Romania (Basart et al., 2012; Nickovic et al., 2001; Pérez et al., 2006).

- Hybrid Single-Particle Lagrangian Integrated Trajectory (HYSPLIT) model, a complete system for computing both simple air parcel trajectories and complex dispersion, also comprising capabilities for deposition simulations. The model uses the existing meteorological forecast fields from regional or global models to compute advection, stability and subsequent dispersion (Draxler and Rolph, 2015);

- The Cloud Aerosol Lidar with orthogonal Polarization (CALIOP) system, on board of the Cloud-Aerosol Lidar and Infrared Pathfinder Satellite Observations (CALIPSO) platform, is based on the elastic-backscatter Lidar used for aerosols and cloud investigation. The CALIOP is providing level 1 products, high-resolution profiles of the attenuated backscattered radiation by aerosols and clouds at visible $(532 \mathrm{~nm})$ and near-infrared wavelengths $(1064 \mathrm{~nm})$ and depolarized backscattered radiation using the visible channel (at $532 \mathrm{~nm}$ ). With previously developed algorithms (Winker et al., 2009), level 2 products [classification of different features by layer type, e. g. clouds, aerosols type like Saharan or mineral dust, biomass burning, urban/industrial, the extinction coefficient profile and total column aerosol optical depth (AOD) for a defined Lidar ratio for each detected aerosol layer] are estimated. Mamouri et al (Mamouri et al., 2009) and Pappalardo et al (Pappalardo et al., 2010) have shown that level 1 attenuated backscatter profiles are in reasonable agreement with ground-based Lidar measurements.

\section{Results and discussions}

The data from July 2012, considered as a hot summer month, were acquired since the aerosols optical properties vary from season to season, as shown by Mihai and Stefan (Mihai and Stefan, 2011). Using data from AERONET and analysing the Ångstrom and SSA parameters, we selected the possible Saharan dust intrusion events. A decrease in the Ångstrom parameter (specially for values lower than 1.5 at $440-870 \mathrm{~nm}$ ) indicates an increase of number of particles with a diameter greater than $1 \mu \mathrm{m}$ (coarse mode) from the volumetric distributions retrieval while an increase of SSA with increasing wavelength (from $440 \mathrm{~nm}$ to $1020 \mathrm{~nm}$, with SSA values between 0.91 and 0.99) indicates a dust influence (Dubovik et al., 2002; Giles et al., 2012). Thus, an analysis of selected days (the $3^{\text {rd }}, 4^{\text {th }}, 15^{\text {th }}$ and $25^{\text {th }}$ of July 2012) presenting this trend was made, and we validated the presence of Saharan dust with data from the HYSPLIT and BSC 
DREAM models, as well as data acquired through the AERONET, as will be seen below.

As previously reported by Unga et al. (2013), July 2012 studies on the tropospheric aerosols above Iasi revealed major influence of urban and industrial aerosols on the air quality in this region. Afterwards, Cazacu et al. have proven that the Iasi_LOASL monitoring site is specific for urban/industrial aerosols type with influences of biomass burning and mineral dust especially when Saharan dust events occur (Cazacu et al., 2015). Thus, in all AERONET data the presence of urban/industrial aerosols was always registered over the studied site.

Concerning the present study, by applying the HYSPLIT model for the days of $3^{\text {rd }}$, $4^{\text {th }}, 15^{\text {th }}$ and $25^{\text {th }}$ of July 2012 in which the Ångstrom coefficient had a decreasing behavior below 1.4 (the highlighted dates in Fig. 1) and the SSA parameter varied from 0.91 (at $440 \mathrm{~nm}$ ) up to 0.99 (at $1020 \mathrm{~nm}$ ) with a very low spherical particle fraction $(0.2 \div 6.6)$, results indicating the presence of Saharan dust have been obtained (Fig. 2).

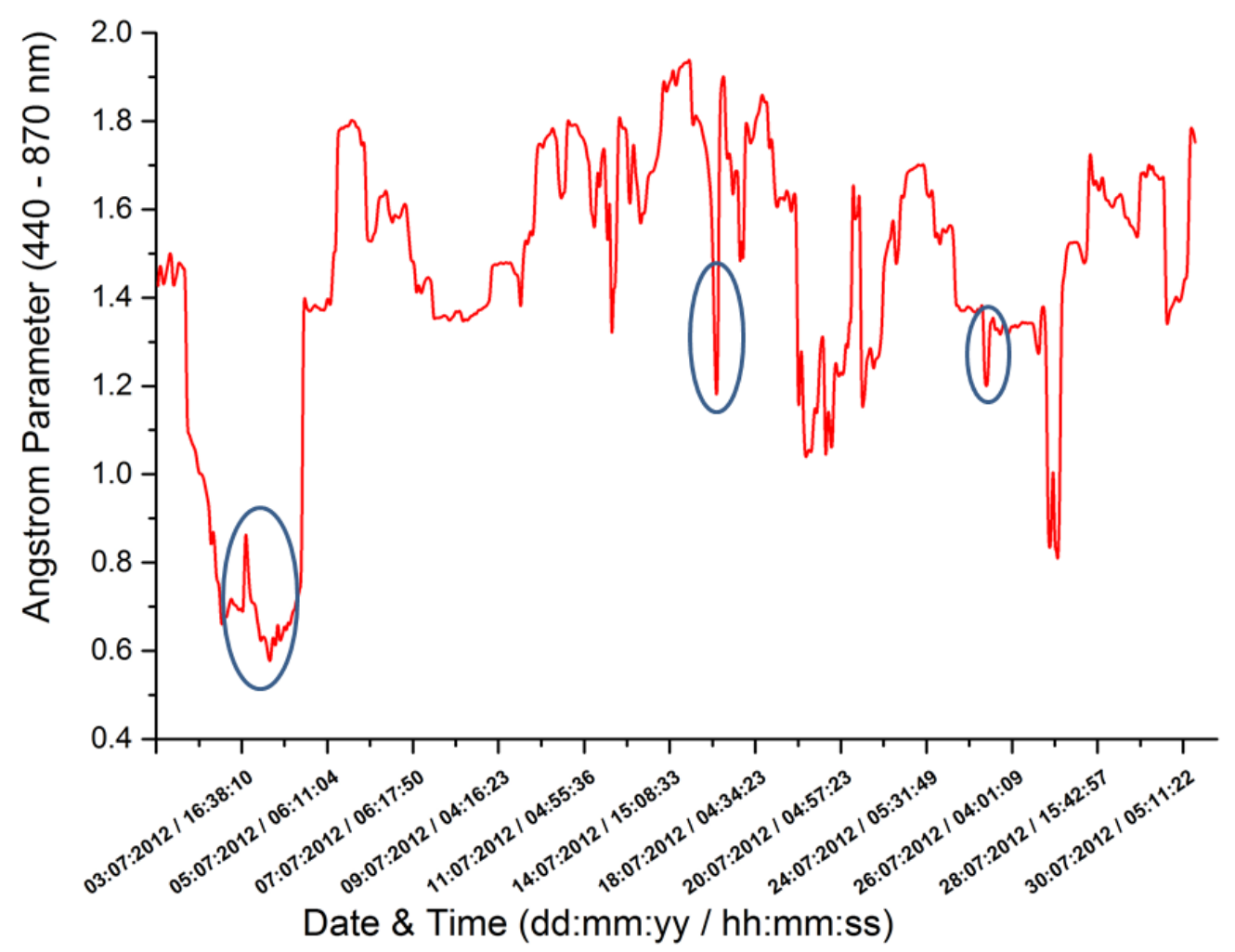

Figure 1. Variation of Angstrom parameter during July 2012.

It can be observed that these intrusion events are originating from Sahara desert. These results are in agreement with the BSC DREAM model, confirming the presence of Saharan dust for $15^{\text {th }}$ and $25^{\text {th }}$ of July 2012 (Fig. 3). Even though for the days of $3^{\text {rd }}$ and $4^{\text {th }}$ of July 2012 the BSC DREAM model does not agree with the presence of Saharan dust above the observation site, particle trajectories indicated by HYSPLIT suggest the Sahara desert as possible origin of measured. The presence of Saharan dust for these days was previously shown by Unga et al (2013) taking into account the Lidar ratio from AERONET data. The given uncertainties are ruled out by comparison with 
previous observation quantities such as: the Angstrom coefficient, the Single Scattering Albedo (SSA), and the LIDAR report calculated by AERONET.
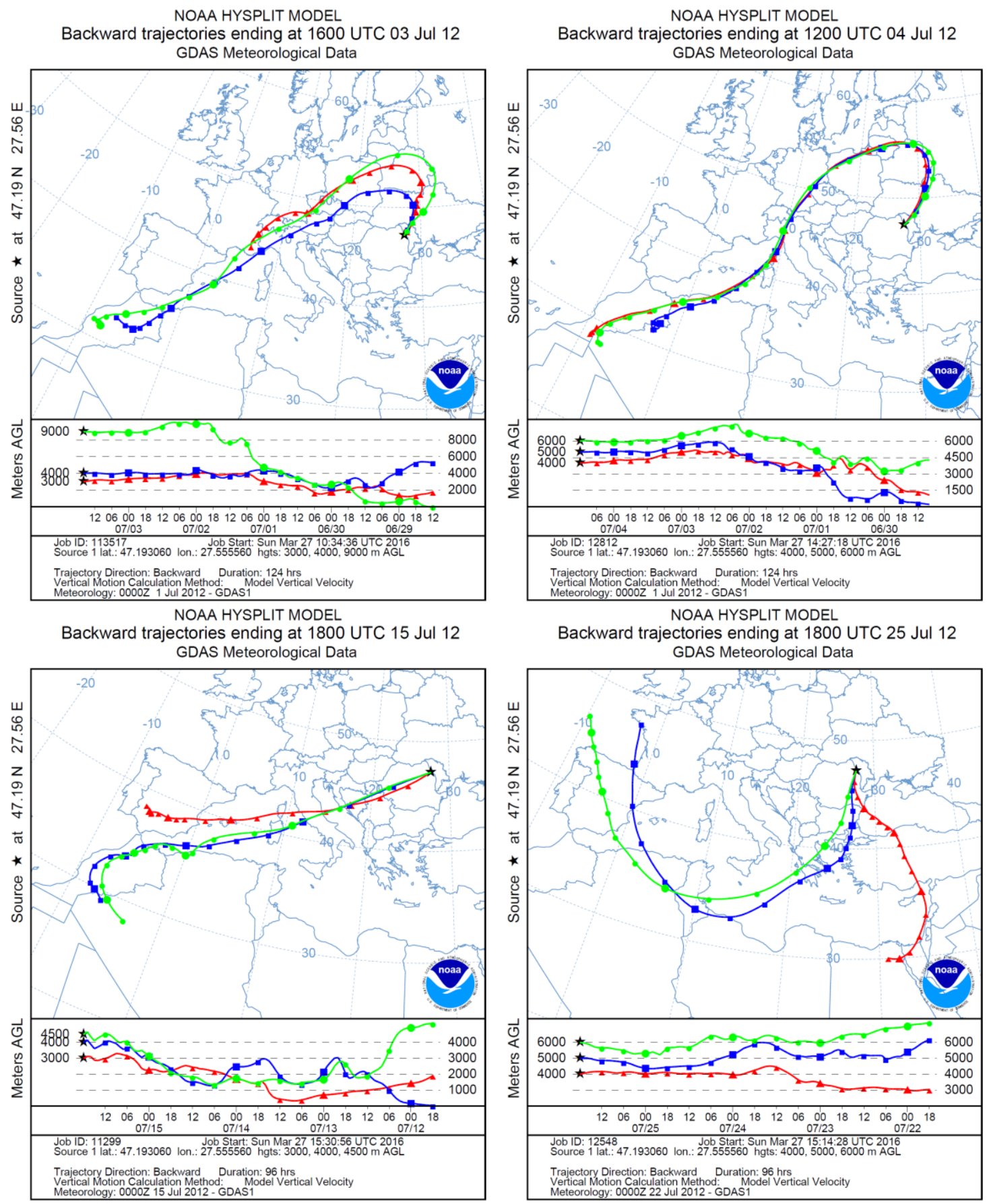

Figure 2. Air mass trajectories from HYSPLIT model.

All the above-mentioned parameters indicate that in fact we are dealing with Saharan dust, since significant drops of the Ångstrom coefficient from 1.5 to 0.5 and $S_{A E R O N E T}$ from $50 \mathrm{sr}$ to $30 \mathrm{sr}$ are recorded. Although the concentration is rather small, the optical quantities measured by the solar photometer correspond to those reported for Saharan 
dust class-type dust (Ansmann et al., 2011, 2009; Muller et al., 2010, 2009; Unga et al., 2013).

By analyzing data gathered for high altitudes, the local influence can be disregarded, thus obtaining additional information on the influence of Saharan dust over the local air quality. The concentration is rather different and quantitative analysis provided by the BSC DREAM indicates variations of the surface density from 0.05 to $0.50 \mathrm{~g} / \mathrm{m}^{2}$ over the observation site.

As can be seen from Figure 3, 15 and 25 July 2012 as clear days and Saharan dust influence days are confirmed by AERONET (Fig. 1) and HYSPLIT (Fig. 2). The absence of cloudiness is confirmed by both the BSC DREAM model and the meteorological data using the EUMETSAT satellite database - European Organization for the Exploitation of Meteorological Satellites (EUMETSAT, 2012). The abovementioned models and experimental data are required to use the MAP3D chemical model.
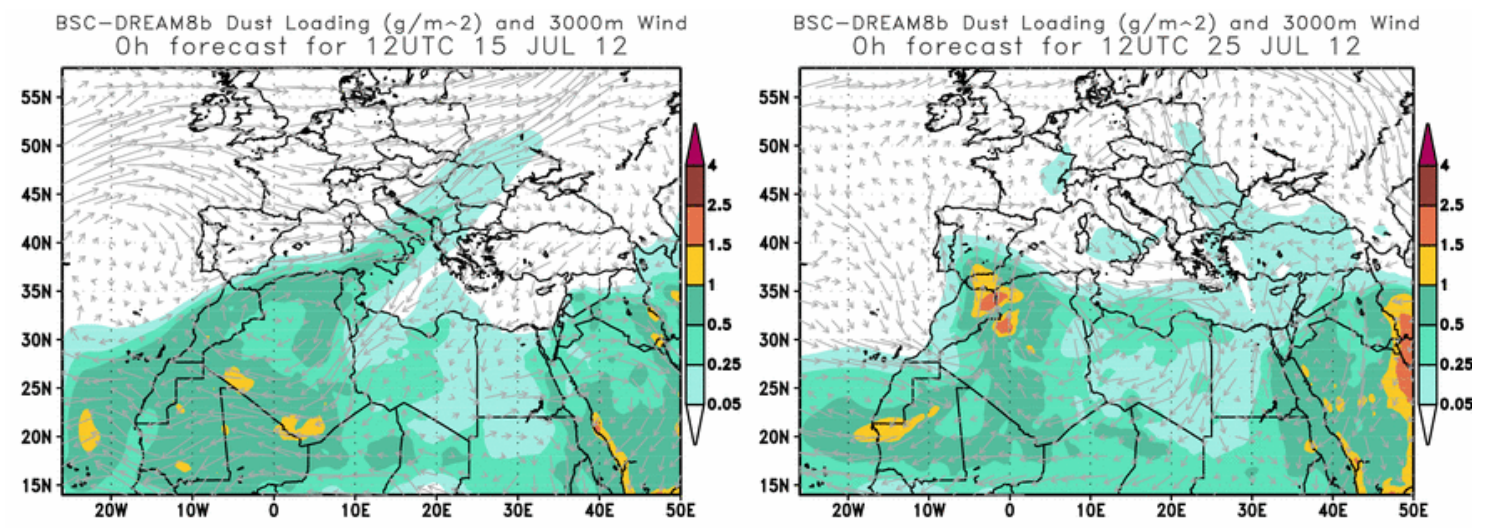

Figure 3. Saharan dust loading by DREAM forecast for July $15^{\text {th }}$ and July $25^{\text {th }}, 2012$.

As it can be shown for the $3^{\text {rd }}, 4^{\text {th }}, 15^{\text {th }}$ and $25^{\text {th }}$ July 2012, the MAP3D model forecasts an increase of the $\mathrm{PM}_{10}$ concentration (Fig. 4). These results are calculated for troposphere, indicating the daily maximum values for altitudes up to $8 \mathrm{~km}$. The complete series from July 2012, indicates that $\mathrm{PM}_{10}$ concentration increased over the entire tropospheric column (up to $8 \mathrm{~km}$ ).

Besides, as it can be easily observed, a new concentration increase is forecasted starting with 19 July. By appealing to HYSPLIT and BSC DREAM models, we cannot confirm any additional intrusion of Saharan dust. The data acquired on 19 July indicate the strong necessity of gathering data from as many sources as possible.

Since the MAP3D model indicated an increase in PM10 concentration for 24 to 25 July and the DREAM model forecasted a powder density similar to that recorded on the 15 July (Fig. 3), these data were completed with products derived from the CALIPSO Lidar measurements. The total backscattering coefficient recorded by CALIPSO for the 00:35 to 00:48 interval (UTC) is given (Fig. 5 - up). The marked area represents the Lidar signal from atmospheric constituents. Appealing to inversion methods for calculation of optical parameters using the Lidar signal, a classification of the aerosols is given (Fig. 5 - down). From the data gathered by CALIPSO, a dispersion of the Saharan dust up to $5 \mathrm{~km}$ altitude can be emphasized. One can state that acquired experimental data match the forecast data. 


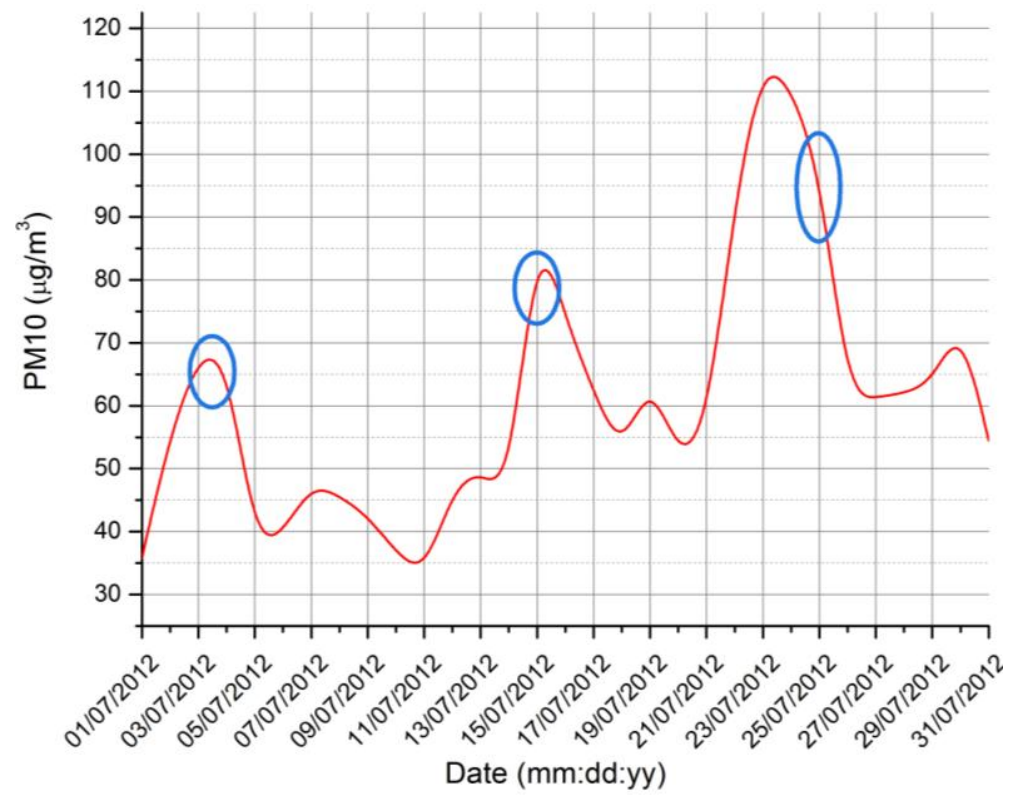

Figure 4. Variation of daily maximum concentration of $P M_{10}$ for July 2012 from MAP3D model.
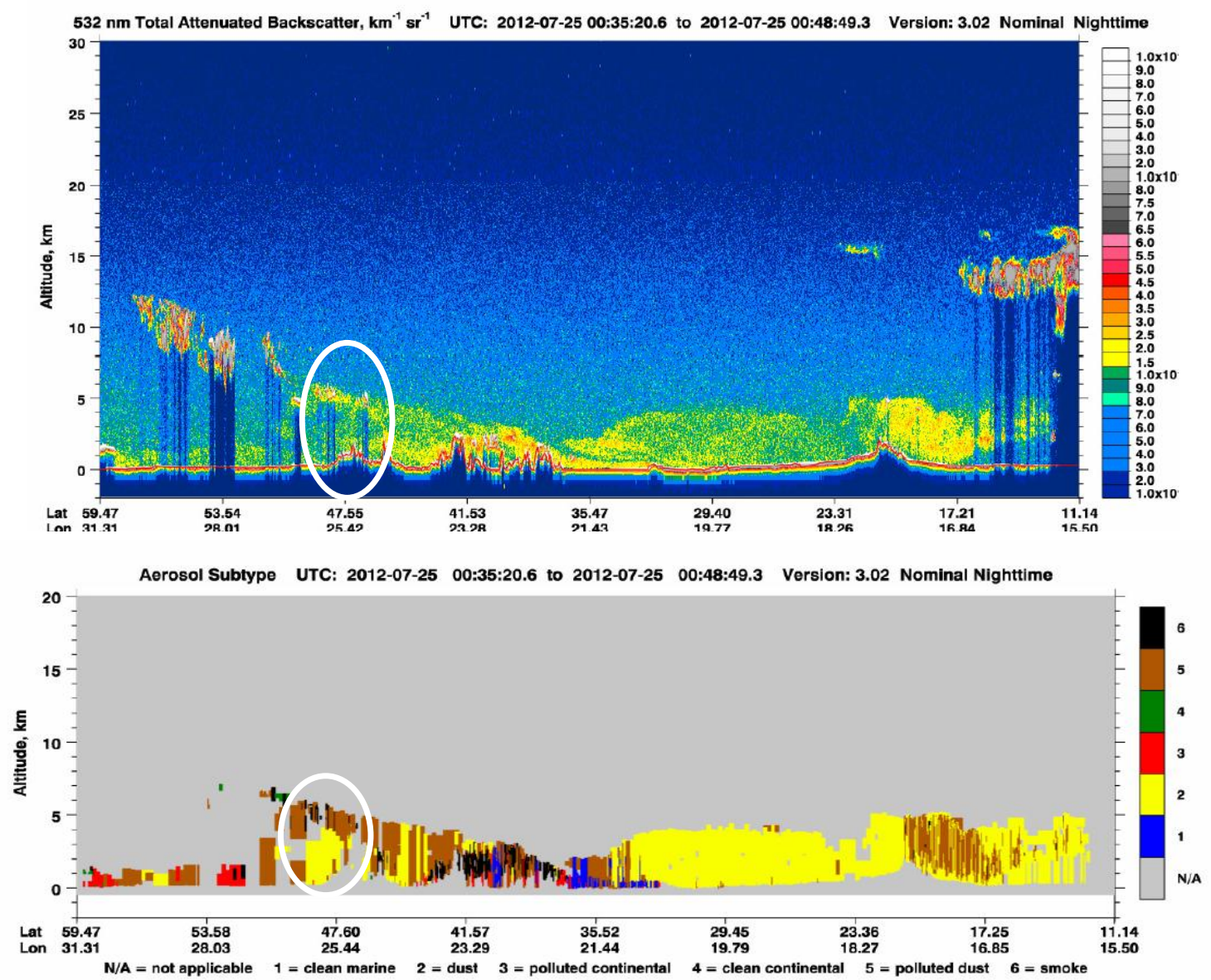

Figure 5. (up): $532 \mathrm{~nm}$ backscatter Lidar profile from CALIPSO and (down): aerosol type classification. 
The influence of the Saharan dust storms over the local climate can be quantified at last. Recent studies indicate variations of ozone concentrations during the Saharan dust events (Frouin and McPherson, 2012; Ohde and Siegel, 2012). A decrease in the ozone concentration was explained by the fact that Saharan dust absorbs in the wavelength range below $440 \mathrm{~nm}$. Another observation indicates a decrease in UV solar radiation intensity reaching the ground level, while the infrared spectrum is not affected. Based on these observations, a parameter closely monitored was the tropospheric ozone concentration.

In our case, the influence of Saharan dust over the tropospheric ozone production was not observed. Given that the data were gathered during clear days, the influence of atmospheric clouds can be excluded. As can be inferred from Figure 6, the variation of the tropospheric ozone concentration may be explained by the following equations (Cazacu et al., 2011; Seinfeld and Pandis, 2006):

$$
\begin{aligned}
& {\left[\mathrm{NO}_{3}+h v(\lambda<700 \mathrm{~nm})\right] \rightarrow \mathrm{NO}+\mathrm{O}_{2}} \\
& {\left[\mathrm{NO}_{3}+h v(\lambda<7580 \mathrm{~nm})\right] \rightarrow \mathrm{NO}_{2}+\mathrm{O}} \\
& {\left[\mathrm{NO}_{2}+h v(\lambda<420 \mathrm{~nm})\right]+\mathrm{O}_{2} \rightarrow \mathrm{NO}+\mathrm{O}_{3}}
\end{aligned}
$$

As instance, the 3D distribution of the ozone given by the MAP3D model is not uniform up to altitudes as high as $8 \mathrm{~km}$, as a consequence of the typical chemical reaction of ozone in the atmosphere (Fig. 7). Furthermore, no observable influence of the Saharan dust was noticed over our ground observatory, due to its small concentration.

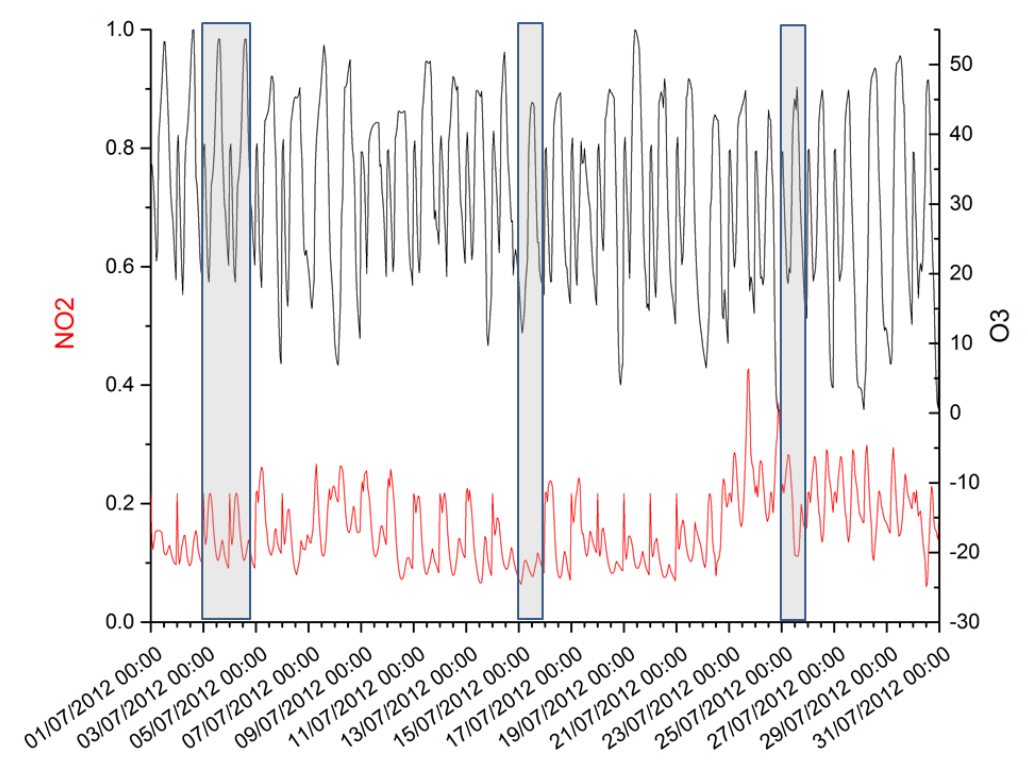

Figure 6. Variation of $\mathrm{NO}_{2}$ and $\mathrm{O}_{3}$ concentrations during July 2012 forecasted by MAP3D model (ground level). 

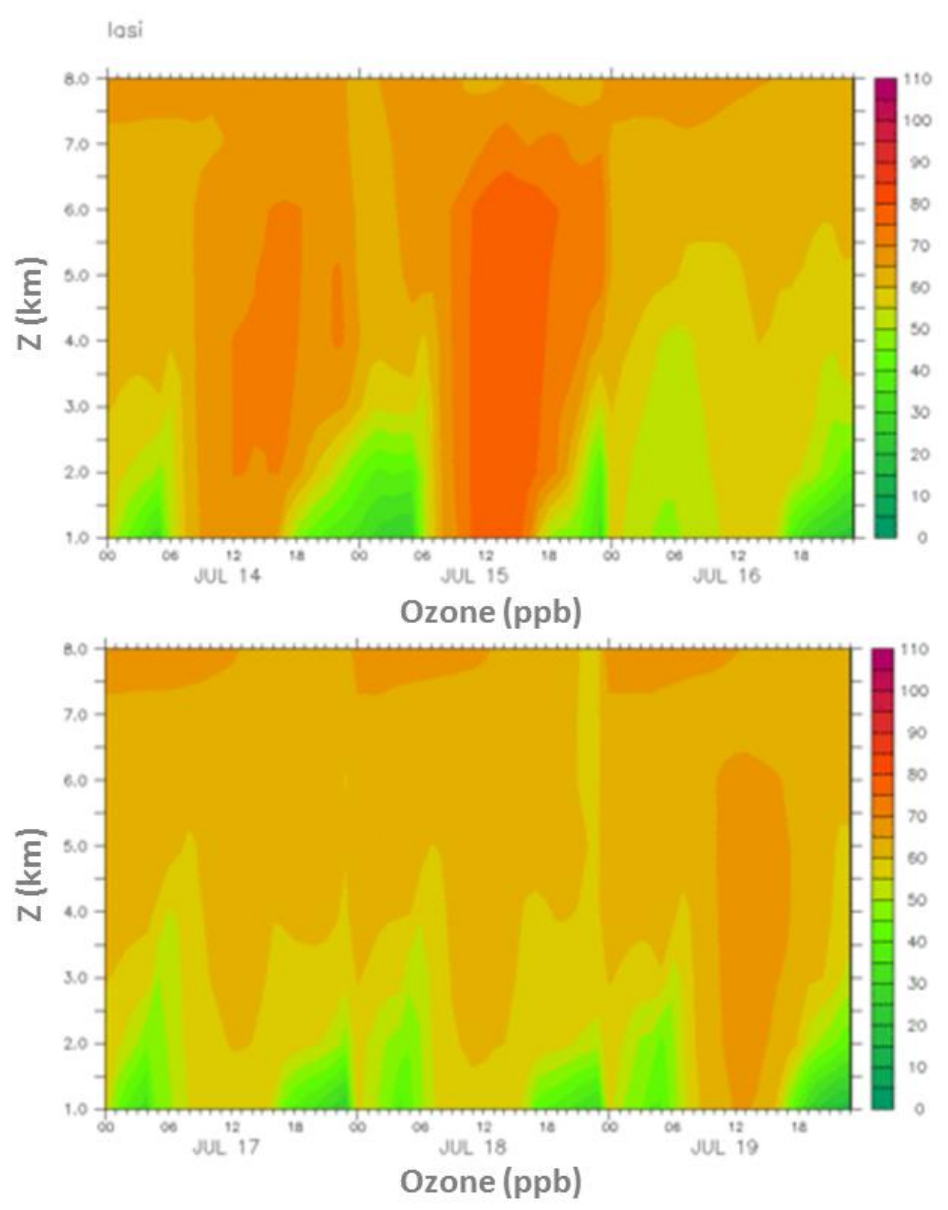

Figure 7. Three-dimensional distribution of $\mathrm{O}_{3}$ computed by MAP3D model (up to $8 \mathrm{~km}$ ).

\section{Conclusions}

The impact of Saharan dust in low and middle troposphere on the behavior of aerosol optical properties was emphasized using modern remote sensing techniques (sun photometer, CALIPSO) and modelling approaches (MAP3D, HYSPLIT, DREAM models).

On the $3^{\text {rd }}, 4^{\text {th }}, 15^{\text {th }}$ and $25^{\text {th }}$ of July 2012 , AERONET data show values between 0.6 - 1.5 of Ångstrom parameter and values between $0.91 \div 0.99$ of SSA at an increase of wavelengths from $440 \mathrm{~nm}$ to $1020 \mathrm{~nm}$. Although these values indicate the presence of mineral dust, the AERONET Lidar ratio (e.g. 30 sr), HYSPLIT data, DREAM model and CALIPSO satellite data confirmed also the influence of Saharan dust load over Iasi_LOASL monitoring site.

The influence of Saharan dust on the tropospheric ozone production has not been clearly observed, probably because of strong absorption of UV-vis radiation $(\lambda<420 \mathrm{~nm})$ by dust particles. The variations of ozone and nitrogen dioxide concentrations are not directly related to Saharan dust loadings and only some seasonal variations are emphasized.

Further complementary measurements are required to fully understand the impact of Saharan dust on the ozone molecules at different altitudes in the troposphere using UVmolecular emission spectroscopy. 
Acknowledgements. This work was supported by the Romanian Space Agency (ROSA) within Space Technology and Advanced Research (STAR) Program (Project nr. 98/29.11.2013) and by the strategic grant POSDRU/159/1.5/S/137750, Project "Doctoral and Postdoctoral programs support for increased competitiveness in Exact Sciences research" cofinanced by the European Social Found within the Sectorial Operational Program Human Resources Development 2007 - 2013.

\section{REFERENCES}

[1] Ansmann, A., Petzold, A., Kandler, K., Tegen, I., Wendisch, M., Muller, D., Weinzierl, B., Muller, T., Heintzenberg, J. (2011): Saharan Mineral Dust Experiments SAMUM-1 and SAMUM-2: What have we learned?. - Tellus, Series B: Chemical and Physical Meteorology 63(4): 403-429.

[2] Ansmann, A., Tesche, M., Knippertz, P., Bierwirth, E., Althausen, D., Müller, D., Schulz, O. (2009): Vertical profiling of convective dust plumes in southern Morocco during SAMUM. - Tellus, Series B: Chemical and Physical Meteorology 61(1): 340-353.

[3] Basart, S., Pérez, C., Nickovic, S., Cuevas, E., Baldasano, J.M. (2012): Development and evaluation of the BSC-DREAM8b dust regional model over Northern Africa, the Mediterranean and the Middle East. - Tellus B 64: 18539.

[4] Belegante, L., Talianu, C., Nemuc, A., Nicolae, D.N. (2011): Detection of local weather events from multiwavelength lidar measurements during the EARLI09 campaign. Romanian Journal of Physics 56(3-4): 484-494.

[5] Cattrall, C., Reagan, J., Thome, K., Dubovik, O. (2005): Variability of aerosol and spectral lidar and backscatter and extinction ratios of key aerosol types derived from selected Aerosol Robotic Network locations. - Journal of Geophysical Research D: Atmospheres 110(10): 1-13.

[6] Cazacu, M.M., Timofte, A., Balin, I., Dimitriu, D.G., Gurlui, S. (2011): Complementary atmospheric urban pollution studies in the North-East region of Romania, Iasi county. Environmental Engineering and Management Journal 10 (1): 139-145.

[7] Cazacu, M.M., Timofte, A., Talianu, C., Nicolae, D., Danila, M.N., Unga, F., Dimitriu, D.G., Gurlui, S. (2012): Grimsvotn Volcano: atmospheric volcanic ash cloud investigations, modelling-forecast and experimental environmental approach upon the Romanian area. - Journal of Optoelectronics and Advanced Materials 14(5-6): 517-522.

[8] Cazacu, M.M., Timofte, A., Unga, F., Albina, B., Gurlui, S. (2015): AERONET data investigation of the aerosol mixtures over Iasi area, One-year time scale overview. Journal of Quantitative Spectroscopy and Radiative Transfer 153: 57-64.

[9] Couach, O., Kirchner, F., Jimenez, R., Balin, I., Perego, S., Van Den Bergh, H. (2004): A development of ozone abatement strategies for the Grenoble area using modeling and indicators. - Atmospheric Environment 38(10): 1425-1436.

[10] Draxler, R.R., Rolph, G.D. (2015): HYSPLIT (HYbrid Single-Particle Lagrangian Integrated Trajectory) Model access via NOAA ARL READY Website. [Online]. Available from: http://ready.arl.noaa.gov/HYSPLIT.php.

[11] Dubovik, O., Holben, B., Eck, T.F., Smirnov, A., Kaufman, Y.J., King, M.D., Tanré, D. Slutsker, I. (2002): Variability of Absorption and Optical Properties of Key Aerosol Types Observed in Worldwide Locations. - Journal of the Atmospheric Sciences 59(3): 590-608.

[12] EUMETSAT (2012): Exploitation of Meteorological Satellites, Satellite images database from July of 2012. [Online]. Available from: http://www.eumetsat.int.

[13] Giles, D.M., Holben, B.N., Eck, T.F., Sinyuk, A., Smirnov, A., Slutsker, I., Dickerson, R.R., Thompson, A.M., Schafer, J.S. (2012): An analysis of AERONET aerosol absorption properties and classifications representative of aerosol source regions. Journal of Geophysical Research: Atmospheres 117: D1720. 
[14] Gothard, M., Nemuc, A., Radu, C., Dascalu, S. (2014): An intensive case of saharan dust intrusion over south east Romania. - Romanian Reports in Physics 66(2): 509-519.

[15] Haywood, J.M., Pelon, J., Formenti, P., Bharmal, N., Brooks, M., Capes, G., Chazette, P., Chou, C., Christopher, S., Coe, H., Cuesta, J., Derimian, Y., Desboeufs, K., Greed, G., Harrison, M., Heese, B., Highwood, E.J., Johnson, B., Mallet, M., et al. (2008): Overview of the Dust and Biomass-burning Experiment and African Monsoon Multidisciplinary Analysis Special Observing Period. - Journal of Geophysical Research 113: D00C17.

[16] Holben, B.N., Eck, T.F., Slutsker, I., Tanré, D., Buis, J.P., Setzer, A., Vermote, E., Reagan, J.A., Kaufman, Y.J., Nakajima, T., Lavenu, F., Jankowiak, I., Smirnov, A. (1998): AERONET - A Federated Instrument Network and Data Archive for Aerosol Characterization. - Remote Sensing of Environment 66(1): 1-16.

[17] Labzovskii, L., Toanca, F., Stefan, S. (2014): Determination of saharan dust properties over bucharest, Romania part 1: Procedures and algorithms. - Romanian Journal of Physics 59(9-10): 1084-1096.

[18] Mamouri, R.E., Amiridis, V., Papayannis, A., Giannakaki, E., Tsaknakis, G. and Balis, D.S. (2009): Validation of CALIPSO space-borne-derived attenuated backscatter coefficient profiles using a ground-based lidar in Athens, Greece. - Atmospheric Measurement Techniques 2(2): 513-522.

[19] Mihai, L., Stefan, S. (2011): Temporal Variation of Aerosol Optical Properties at Măgurele, Romania. - Journal of Atmospheric and Oceanic Technology 28: 1307-1316.

[20] Muller, D., Ansmann, A., Freudenthaler, V., Kandler, K., Toledano, C., Hiebsch, A., Gasteiger, J., Esselborn, M., Tesche, M., Heese, B., Althausen, D., Weinzierl, B., Petzold, A. and Von Hoyningen-Huene, W. (2010): Mineral dust observed with AERONET Sun photometer, Raman lidar, and in situ instruments during SAMUM 2006: Shapedependent particle properties. - Journal of Geophysical Research Atmospheres 115(11): $1-18$.

[21] Muller, D., Heinold, B., Tesche, M., Tegen, I., Althausen, D., Arboledas, L.A., Amiridis, V., Amodeo, A., Ansmann, A., Balis, D., Comeron, A., D’amico, G., Gerasopoulos, E., Guerrero-rascado, J.L., Freudenthaler, V., Giannakaki, E., Heese, B., Iarlori, M., Knippertz, P., et al. (2009): EARLINET observations of the 14-22-May long-range dust transport event during SAMUM 2006: Validation of results from dust transport modelling. - Tellus, Series B: Chemical and Physical Meteorology 61(1): 325-339.

[22] Nickovic, S., Kallos, G., Papadopoulos, A., Kakaliagou, O. (2001): A model for prediction of desrt dust cycle in the atmosphere. - Journal of Geophysical Research 106(D16): 18113.

[23] Nicolae, D., Belegante, L., Nemuc, A. (2010): Laser remote sensing in atmosphere investigation. - Optoelectronics and Advanced Materials - Rapid Communications 4(12): 1946-1951.

[24] Ohde, T., Siegel, H. (2012): Impacts of Saharan dust and clouds on photosynthetically available radiation in the area off Northwest Africa. - Tellus B 64: 17160.

[25] Papayannis, A., Nicolae, D., Kokkalis, P., Binietoglou, I., Talianu, C., Belegante, L., Tsaknakis, G., Cazacu, M.M., Vetres, I. and Ilic, L. (2014): Optical, size and mass properties of mixed type aerosols in Greece and Romania as observed by synergy of lidar and sunphotometers in combination with model simulations: A case study. - Science of The Total Environment 500-501:277-294.

[26] Pappalardo, G., Wandinger, U., Mona, L., Hiebsch, A., Mattis, I., Amodeo, A., Ansmann, A., Seifert, P., Linné, H., Apituley, A., Alados Arboledas, L., Balis, D., Chaikovsky, A., D’Amico, G., De Tomasi, F., Freudenthaler, V., Giannakaki, E., Giunta, A., Grigorov, I., et al. (2010): EARLINET correlative measurements for CALIPSO: First intercomparison results. - Journal of Geophysical Research 115: D00H19.

[27] Pérez, C., Nickovic, S., Pejanovic, G., Baldasano, J.M. and Özsoy, E. (2006): Interactive dust-radiation modeling: A step to improve weather forecasts. - Journal of Geophysical Research 111: D16206. 
[28] Seinfeld, J.H., Pandis, S.N. (2006): Atmospheric Chemistry and Physics: From Air Pollution to Climate Change, $2^{\text {nd }}$ Edition. - In: John Wiley and Sons Inc., New Jersey.

[29] Shon, Z.-H., Madronich, S., Song, S.-K., Flocke, F.M., Knapp, D.J., Anderson, R.S., Shetter, R.E., Cantrell, C.A., Hall, S.R., Tie, X. (2008): Characteristics of the NO- $\mathrm{NO}_{2}$ $\mathrm{O}_{3}$ system in different chemical regimes during the MIRAGE-Mex field campaign. Atmospheric Chemistry and Physics 8(23): 7153-7164.

[30] Timofte, A., Cazacu, M.M., Radulescu, R., Belegante, L., Dimitriu, D.G., Gurlui, S. (2011): Romanian lidar investigation of the Eyjafjallajokull volcanic ash. Environmental Engineering and Management Journal 10(1): 91-97.

[31] Unga, F., Cazacu, M.M., Timofte, A., Bostan, D., Mortier, A., Dimitriu, D.G., Gurlui, S., Goloub, P. (2013): Study of tropospheric aerosol types over Iasi , Romania , during summer of 2012. - Environmental Engineering and Management Journal 12(2):297-303.

[32] Winker, D.M., Vaughan, M.A., Omar, A., Hu, Y., Powell, K.A., Liu, Z., Hunt, W.H., Young, S.A. (2009): Overview of the CALIPSO Mission and CALIOP Data Processing Algorithms. - Journal of Atmospheric and Oceanic Technology 26(11): 2310-2323. 